\title{
KONTRIBUSI KEHARMONISAN KELUARGA DALAM PERKEMBANGAN KETERAMPILAN SOSIAL SISWA KELAS V DI SDN BANGUN HARJO
}

\author{
Seka Andrean ${ }^{1}$, Erni Munastiwi ${ }^{2}$ \\ ${ }_{1}^{1}$ Mahasiswa Pascasarjana Universitas Islam Negeri Sunan Kalijaga Yogyakarta \\ ${ }^{2}$ Dosen Pascasarjana Universitas Islam Negeri Sunan Kalijaga Yogyakarta \\ ${ }^{*}$ E-mail: sekaandrean28@gmail.com ${ }^{1}$,erni.munastiwi@uin.suka.ac.id ${ }^{2}$
}

\begin{abstract}
Abstrak
Agar anak memiliki keterampilan sosial dan komunikasi yang baik, maka perlu adanya keharmonisan didalam lingkungan keluarga. Lingkungan keluarga merupakan tempat dimana anak dibesarkan dan merupakan lingkungan yang pertama kali dijalani oleh seorang anak dalam mengarungi hidupnya, sehingga apa yang dilihat dan dirasakan oleh anak dalam keluarga akan dapat mempengaruhi pertumbuhan dan perkembangan pribadi seorang anak. Penelitian ini bertujuan untuk mengetahui kontribusi keharmonisan keluarga dalam perkembangan keterampilan sosial anak. Peneliti melakukan penelitian di SDN Bangun Harjo dengan menggunakan metode kualitatif. teknik pengumpulan data yang digunakan adalah wawancara, observasi dan dokumentasi yang subjeknya 10 siswa dan keluarga siswa kelas V di SDN Bangun Harjo. Analisis data dilakukan dengan menganalisis semua data dari hasil penelitian, supaya dapat dijadikan satu kesatuan kemudian diverifikasi. Berdasarkan penelitian bahwa kontribusi keharmonisan keluarga dalam perkembangan keterampilan sosial yaitu Menciptakan kehidupan beragama dalam keluarga, Mempunyai waktu bersama keluarga, Mempunyai komunikasi yang baik antar anggota keluarga, Saling menghargai antar sesama anggota keluarga. Kualitas dan kuantitas konflik yang minim.
\end{abstract}

Kata kunci: Keharmonisan, Keluarga, Keterampilan Sosial.

\section{PENDAHULUAN}

Keluarga merupakan lingkungan yang pertama bagi seorang anak, karena dilingkungan keluarga pertama-tama anak mendapatkan pengaruh (Nur Ahid, 2010: 3). Dalam masyarakat, keluarga dikatakan unit sosial terkecil yang terdiri dari suami, istri dan anak (Eriyanti, Susilo, dan Riyanto, 2019: 10). Keluarga juga tempat pertama dan yang utama di mana anak-anak belajar. Dari keluarga, mereka mempelajari sifat keyakinan, sifat-sifat mulia, komunikasi dan interaksi sosial, serta keterampilan hidup (Helmawati, 2014: 43).

Interaksi sosial juga dipengaruhi oleh suasana yang ada didalam keluarga, suasana tersebut juga dapat mempengaruhi perkembangan emosi, respon efektif anak, remaja dan orang dewasa sebagai anggota keluarga (Saputri, 2014: 376). Keluarga bukan hanya bertugas mendidik anak-anak saja, tetapi juga mampu memberikan peran untuk anak. Perilaku orang tua merupakan kunci bagi kesuksesan mereka dalam mendidik anakanaknya. Secara tidak langsung, apa yang orang tua katakan dan lakukan akan menjadi contoh bagi anaknya (Muchtar dkk, 2013: 68). Anak diharapkan mampu memerankan dirinya sendiri, menyesuaikan diri, mencontoh pola dan tingkah laku dari orang tua serta dari orangorang yang berada dekat dengan lingkungan keluarganya. Jadi peran ayah dan ibu serta seluruh anggota adalah anggota terpenting bagi proses pembentukan dan perkembangan pribadi seorang anak.

Dalam pandangan Islam, anak adalah "amanah" yang harus dijaga dan dirawat dengan baik oleh orang tuanya. Tugas orang tua untuk mendidik dan membesarkan anak, tidak cukup dengan memenuhi kebutuhan materi dan finansialnya saja, tetapi harus benar-benar mendidik secara langsung.

Sesungguhnya orang tua adalah "guru pertama" bagi anak-anak. Semua kata-kata, perilaku, nasehat dan keseluruhan hidup orang tua adalah "kurikulum" utama bagi perkembangan spiritual, intelektual, dan 
emosional (moralitas) anak (Suharsono, 2005: 127). Apa yang terjadi dan dilakukan orang tua dalam suatu keluarga jauh lebih berpengaruh dari sekedar nasehat-nasehat verbal. Dengan demikian, keluarga mempunyai peran dalam membentuk mental anak, baik mental-emosional, mental-intelektual, mental-sosial, dan mental spritual. Seorang anak akan mengalami perkembangan emosional dengan baik, manakala keadaan dalam keluarganya diselimuti dengan keharmonisan dan keserasian antara bapak dan ibunya.

Dalam keluarga yang harmonis, anak akan mendapatkan suatu pengalaman sebagai latihan dasar untuk mengembangkan sikap sosial dan perilaku yang baik. Selain itu anak juga akan mendapat berbagai pengertian mengenai hak dan kewajiban, rasa tanggung jawab, peka dengan lingkungan, komunikasi yang baik, serta rasa empati. Artinya, seorang anak yang hidup dalam keluarga yang diwarnai dengan keakraban dan kehangatan akan terbentuk asas hidup kelompok yang baik sebagai landasan hidupnya di masyarakat.

Sebagian besar siswa yang memiliki keluarga harmonis, mereka pandai mengelola emosinya dan pandai dalam berhubungan sosial dengan teman sebayanya, guru, dan orang-orang yang lebih muda atau dewasa dari dirinya. Mereka mampu menempatkan diri dimana pun dan kapan pun. Begitu pula sebaliknya, mereka yang memiliki keluarga yang broken home, orang tua yang otoriter, orang tua yang terlalu sibuk dengan dunia kerjanya tanpa memperhatikan kondisi psikis anak, dan orang tua yang cenderung acuh pada pendidikan anak, mereka akan tumbuh menjadi pribadi yang kurang mampu menyesuaikan diri dengan lingkungan. Berdasarkan hasil wawancara yang dilakukan dengan salah seorang pendidik, peneliti dapati pada sebagian siswa di SDN Bangun Harjo, Kec. Buay Madang Timur, Kab. OKU Timur, Sumatera Selatan, mereka yang memiliki latar belakang keluarga kurang harmonis cenderung selalu membuat ulah pada teman-teman dan juga guru, tidak jarang mereka menyalah gunakan tata tertib atau peraturan yang ada di sekolah. Ketika bermain dengan teman sebayanya, anak ini selalu ingin dimengerti oleh teman-temannya, kemudian mereka pun mudah sekali marah dengan hal yang sepele. Tugas sekolah tidak pernah dikerjakan, dan sering sekali membolos pada jam pelajaran. Setelah ditelusuri, ternyata mereka memiliki kesenjangan dalam keluarganya. Mereka haus akan perhatian dan kasih sayang dari keluarganya.

Dengan fakta tersebut, keutuhan keluarga dan kepedulian orang tua sangat berpengaruh terhadap anak untuk dapat memiliki keterampilan sosial yang membantu mereka dalam berhubungan sosial dengan lingkungannya. Keluarga terutama orang tua bertanggung jawab atas segala perilaku anak-anaknya, karena mereka yang paling dekat dengan anak sehingga mereka harus mengetahui perkembangan-perkembangan sosial-emosional nya agar kelak anak-anak mereka menjadi sosok anak yang tidak hanya cerdas, melainkan terampil dalam sosial dan bermoral. John Gottman dan Joan DeClaire (2008: 29) mengatakan, orang tua memiliki peluang yang besar untuk mempengaruhi emosional anak-anak mereka dengan menolong mereka mempelajari tingkah laku yang menghibur diri sejak mereka bayi sampai seterusnya.

Berdasarkan penelitian sebelumnya dalam jurnal age hamzanwaadi university yang dilakukan oleh Tresna Dewi tentang Pengaruh Keterlibatan Orangtua Terhadap Perilaku Sosial Emosinal Anak di dapatkan bahwa terdapat pengaruh signifikan keterlibatan orangtua terhadap perilaku sosial emosional anak usia 5-6 tahun dengan nilai sig $<0,05$ dengan koefisien determinasi sebesar $54.3 \%$ dan sisanya dipengaruhi oleh faktor lain. (Dewi, 2018). Hal ini menunjukan bahwasannya keluarga memiliki pengaruh terhadap perilaku sosial pada anak. Persamaan penelitian ini dengan penulis sama sama membahas tentang keluarga dan sosial anak. Perbedaannya penelitian sebelumnya menggunakan metode penelitian kuantitaif dan peneliti menggunakan metode penelitian kualitatif, penelitian sebelumnya membahas tentang sosial emosional anak dan peneliti

\section{Seka Andrean, Erni Munastiwi}


membahas tentang perkembangan keterampilan sosial anak.

Dengan demikian, dari latar belakang di atas, maka penulis tertarik untuk melakukan penelitian dengan judul "Kontribusi Keharmonisan Keluarga Terhadap Perkembangan Keterampilan Sosial Siswa Kelas V di SDN Bangun Harjo". Tujuan dari penelitian ini yaitu untuk mengetahui kontribusi keharmonisan keluarga dalam perkembangan sosial siswa kelas V di SDN Bangun Harjo.

\section{KAJIAN TEORI}

\section{Keharmonisan Keluarga}

Secara terminologi harmonis adalah hal atau keadaan selaras atau serasi; keselarasan; keserasian (Departemen Pendidikan Nasional, 2005: 299). Dan keluarga adalah : "ibu, bapak beserta seluruh anggota isi rumah, satuan kekerabatan yang sangat mendasar dalam masyarakat."(Departemen Pendidikan Nasional, 2005: 536)

Keluarga yang sakinah, mawaddah, warahmah dalam Al-Qur'an surat Ar-Rum ayat 21, adalah keluarga yang penuh kedamaian, cinta dan kasih sayang. Sakinah dalah hal rumah tangga adalah suatu keadaan yang tentram, tenang dan damai sehingga seluruh anggota keluarga merasa nyaman berada di rumah. Sedangkan mawaddah adalah cinta, ketika kedua pasangan saling memiliki cinta maka ia mampu menjalankan kehidupannya dengan baik, rumah tangga pun akan harmonis. dan rahmah adalah kasih sayang, dalam hubungan keluarga rasa kasih sayang haruslah ada di dalamnya, dengan adanya rasa kasih sayang keluarga bisa menjadi lebih harmonis dan memperoleh sebuah kebahagiaan. Kebahagiaan tersebut menjadi benteng yang dapat memperkuat hubungan antar anggota keluarga.

Keharmonisan keluarga bersumber dari kerukunan hidup yang dalam keluarga. Kebiasaan sesama anggota keluarga terdapat hubungan yang nyata, teratur dengan baik, terutama sekali hubungan anak dengan orang tua (Isminayah \& Supandi, 2016: 236). Keharmonisan dalam keluarga dapat menciptakan kebahagiaan yang tak terkira bagi setiap individu. Pasalnya, keluarga adalah lingkup kehidupan yang paling dekat dan sangat berharga. Untuk itu, memahami makna dan pengertian keluarga yang harmonis perlu dilakukan demi mewujudkan keluarga yang bahagia. Keluarga harmonis adalah keluarga yang rukun berbahagia, tertib, disiplin, saling menghargai, penuh pemaaf, tolong menolong dalam kebajikan, memiliki etos kerja yang baik, bertetangga dan saling menghormati, taat mengerjakan ibadah, berbakti pada yang lebih tua, mencintai ilmu pengetahuan dan mamanfaatkan waktu luang dengan hal yang positif dan mampu memenuhi dasar keluarga (Nidyansari, 2018: 265).

Menurut Daradjat dalam (Awi, dkk, 2016: 5) mengemukakan keluarga harmonis adalah keluarga dimana seluruh anggota menjalankan hak dan kewajiban masing-masing, terjalin kasih sayang, saling pengertian, komunikasi dan kerjasama yang baik antara anggota keluarga.

Jadi, keharmonisan keluarga merupakan suatu keadaan keluarga yang serasi atau selaras, terdiri dari suami, istri, dan anak-anak. Dalam kondisi ini setiap anggota keluarga merasakan kenyamanan hidup dan mendapatkan kebahagiaan secara lahir maupun batin, karena rasa cinta, empati, dan solidaritas berpadu menjadi satu. Keluarga sebagai pondasi utama bangunan komunitas, sehingga segala tabiat yang dilakukan anak merupakan gambaran keluarganya. Keluarga berperan untuk memberikan arahan-arahan mengenai segala aspek yang menghubungkan dirinya dengan masyarakat.

\section{Aspek-Aspek Keharmonisan Keluarga}

\section{Seka Andrean, Erni Munastiwi}


Dalam membangun suatu keluarga yang harmonis, terdapat 6 aspek yang harus diperhatikan:

1. Menciptakan kehidupan beragama dalam keluarga.

2. Mempunyai waktu bersama keluarga.

3. Mempunyai komunikasi yang baik antar anggota keluarga.

4. Saling menghargai antar sesama anggota keluarga.

5. Kualitas dan kuantitas konflik yang minim.

6. Adanya hubungan atau ikatan yang erat antar anggota keluarga. (Farida, dkk., 2014: 77)

Keenam aspek tersebut mempunyai hubungan yang erat antar satu dan yang lainnya. Proses pertumbuhan dan perkembangan anak dapat ditentukan dari keenam aspek tersebut. Kualitas hubungan antara orang tua dan anak sangat menentukan sikap dan perilaku sang anak, terutama pada anak yang sudah menginjak usia remaja. Karena remaja telah memiliki kepekaan emosional yang tinggi.

\section{Keterampilan Sosial}

Keterampilan social merupakan bagian dari keterampilan hidup kita atau sering dikenal dengan istilah life skill. Berbagai pendapat ahli tentang life skill telah menyimpulkan bahwa life skill merupakan kecakapan yang dimiliki seseorang untuk berani menghadapi problema hidup dan kehidupan dengan wajar tanpa merasa tertekan, kemudian secara proaktif dan kreatif mencari serta menemukan solusi untuk pemecahannya (Setiawati, 2009: 47).

Keterampilan sosial yakni seni membina hubungan yang sebagian besar merupakan kemampuan mengelola emosi orang lain (Agus Efendi, 2005: 170). Keterampilan sosial juga diartikan sebagai kemampuan individu dalam berkomunikasi dengan orang lain, baik secara verbal maupun non verbal. Remaja yang mempunyai keterampilan sosial akan mampu mengungkapkan perasaannya, baik perasaan positif maupun negatif dalam hubungan interpersonalnya tanpa melukai perasaan siapapun.

Proses sosial adalah suatu interaksi atau hubungan timbal balik atau saling mempengaruhi antar manusia yang berlangsung sepanjang hidupnya didalam masyarakat (Farida Yunistiati, dkk, 2014: 72). Mu'tadin mengemukakan bahwa salah satu tugas perkembangan dari remaja adalah memiliki keterampilan sosial untuk dapat menyesuaikan diri dengan kehidupan sehari-hari dan lingkungan sekitar. Keterampilan sosial baik secara langsung maupun tidak, dapat membantu remaja untuk menyesuaikan diri sesuai dengan harapan masyarakat dan norma-norma yang berlaku. Wujud dari keterampilan sosial ini, meliputi kemampuan berkomunikasi, menjalin hubungan dengan orang lain, menerima pendapat dan kritik dari orang lain, mendengarkan keluhan teman sebaya, dan lain sebagainya. Apabila keterampilan sosial tersebut dapat dikuasai oleh remaja, maka ia akan mampu menyesuaikan diri dengan lingkungan sosialnya. Dan ini berarti remaja tersebut mampu mengembangkan psikososialnya dengan maksimal.

\section{Ciri-ciri Keterampilan Sosial}

Gresham \& Reschly sebagaimana dikutib oleh Sari dan Kristiawan (2017: 311) mengidentifikasikan keterampilan sosial dengan beberapa ciri, antara lain:

a. Perilaku Interpersonal

Perilaku interpersonal menyangkut keterampilan yang digunakan selama berinteraksi sosial dengan orang lain. Hal ini biasa disebut dengan keterampilan menjalin persahabatan.

b. Perilaku yang Berhubungan Dengan Diri Sendiri

\section{Seka Andrean, Erni Munastiwi}


Perilaku ini merupakan ciri dari individu yang dapat mengatur dirinya sendiri dalam situasi sosial, seperti halnya: mampu menghadapi stress, mampu memahami perasaan orang lain, mampu mengontrol amarah, dan lain sebagainya.

c. Perilaku yang Berhubungan Dengan Kesuksesan Akademis

Perilaku ini berhubungan dengan hal-hal yang mendukung prestasi belajar siswa di sekolah, seperti: memperhatikan dan mendengarkan guru, mengerjakan tugas sekolah dengan baik, menaati peraturanperaturan sekolah, dan lain sebagainya.

d. Penerimaan Teman Sebaya

Keterampilan ini akan menguntungkan setiap individu, karena individu yang mudah bergaul akan disenangi banyak orang. Sebaliknya, jika seseorang keterampilan sosialnya rendah, ia cenderung akan dijauhi teman sebayanya. Beberapa bentuk perilaku yang dimaksud adalah : tidak membeda-bedakan teman, menangkap emosi orang lain dengan cepat dan tepat, mampu memberi dan menerima informasi, dan lain sebagainya.

e. Keterampilan Berkomunikasi

Komunikasi sangat diperlukan untuk menjalin hubungan sosial yang baik. Wujud dari keterampilan ini adalah: memberikan feedback, mendengarkan lawan bicara, menjadi pendengar yang responsif, bertutur kata dengan bahasa yang luwes, dan lain sebagainya.

\section{Faktor-faktor yang Mempengaruhi Keterampilan Sosial}

Keterampilan sosial dipengaruhi oleh beberapa faktor, antara lain faktor keluarga, lingkungan, serta kemampuan dalam penyesuaian diri (Musdalipah dkk, 2015: 9).

\section{METODE/EKSPERIMEN}

Penelitian ini menggunakan metode deskriptif dengan pendekatan kualiatif (Wina Sanjaya, 2013: 203). Yang mana fokus dari penelitian ini untuk mendeskripsikan tentang kontribusi keharmonisan keluarga terhadap perkembangan keterampilan sosial siswa V. Penelitian ini dilaksanakan di SDN Bangun Harjo. Peneliti melakukan observasi secara langsung pada keluarga siswa yang dijadikan subjek penelitian. Sumber data dalam penelitian ini adalah 10 siswa dan keluarga siswa kelas V di SDN Bangun Harjo.

Teknik pengumpulan menggunakan observasi, wawancara dan dokumentasi digunakan untuk data tambahan. Teknik observasi dilakukan dengan mengamati dan menganalisis keadaan 10 keluarga siswa yang harmonis dan mengamati keterampilan sosial yang dimiliki siswa tersebut. Wawancara dilakukan dengan teknik wawancara tak terstruktur yaitu data wawancara dilakukan dengan cara mengajukan beberapa pertanyaan kepada sepuluh keluarga siswa kelas V di SDN Bangun Harjo. Sedangkan teknik dokumentasi dilakukan dengan cara mengumpulkan dokumentasi mengenai keadaan suatu keluarga dari beberapa siswa kelas $\mathrm{V}$ di SDN Bangun Harjo.

\section{PEMBAHASAN}

Hasil

Penelitian ini dilakukan di SDN Bangun Harjo. Sekolah Dasar ini terletak di Desa Bangun Harjo, Kec. Buay Madang Timur, Kab. OKU Timur, Sumatera Selatan. Sekolah Dasar ini pun merupakan salah satu sekolah yang sudah menggunakan kurikulum 2013 secara baik. Kurikulum 2013 yang diterapkan di sekolah ini tergolong 
berhasil karena mampu meningkatkan keaktifan dan kemandirian siswa dalam belajar, telah diperoleh banyak prestasi di sekolah ini. Selama observasi, penulis menemukan berbagai penerapan yang ada di sekolah ini seperti bel masuk pukul 07.00, sehingga guru-guru dan murid-murid akan datang sebelum pukul tersebut. Kedisiplinan di sekolah ini sangat diutamakan, terlihat dari diwajibkan untuk semua warga SDN Bangun Harjo untuk tepat waktu sampai di sekolah.

Sekolah ini pun menerapkan system go green, dilihat dari luar dan dalam sekolah yang mempunyai tatanan tanaman dan pohon yang rapi. Lebih sejuk lagi ketika masuk kedalam lingkungan sekolah, disediakan taman-taman kecil berikut kolam ikan. Menambah keasrian yang diciptakan di dalam sekolah. Hal ini maksudkan agar didapatkan kenyamanan dari setiap proses pembelajaran yang dilaksanakan disekolah.

Sebagian besar siswa yang ada di sekolah SDN Bangun Harjo ini berasal dari keluarga yang serba berekonomi menengah ke bawah, orang tua mereka secara garis besar hanya seorang petani dan buruh disawah. Hanya beberapa keluarga yang berasal dari keluarga yang berkecukupan. Para orang tua siswa/siswi di sekolah ini begitu perhatian dan peduli dengan anak-anaknya, tak jarang mereka sering menghubungi guru ataupun wali kelas untuk menanyakan perkembangan anaknya selama di sekolah, baik dalam hal akademis ataupun moral. Demikian juga para guru terutama wali kelas, mereka kerap kali melaporkan perkembangan anak pada orang tua. Karena dengan kerja sama antara guru dan orang tua, diharapkan mampu meningkatkan mutu dan kualitas diri siswa.

Akan tetapi, tidak semua siswa di SDN Bangun Harjo mempunyai keluarga yang utuh yakni terdiri dari ayah dan ibu yang lengkap, siswa/siswi di sekolah ini pun ada yang berasal dari keluarga Broken Home dan juga sebaliknya. Oleh karena itu, tidaklah heran apabila kedua orang tua mereka mempunyai cara yang sangat berbeda-beda dalam mendidik dan membina keluarganya, perbedaan inilah yang pada akhirnya membuat seorang anak atau siswa mempunyai kepribadian yang berbeda antar satu dengan yang lainnnya, dan mereka pun mempunyai perbedaan ketika bersosialisasi dengan lingkungan dan sekitarnya.

Dalam pelaksanaannya peneliti melihat secara langsung keadaan keluarga dari sepuluh informan. Peneliti melakukan kunjungan ke rumah-rumah siswa guna mendapatkan data lebih akurat mengenai keluarga harmonis. Selain observasi, peneliti juga melakukan wawancara untuk tabel atau grafik, untuk memperjelas hasil secara verbal.

mendapatkan data keharmonisan keluarga. Kemudian peneliti juga mengamati keterampilan sosial sepuluh siswa kelas $\mathrm{V}$ secara langsung dengan mengamati saat bermain dengan teman sebayanya, selain itu peneliti juga melakukan pendekatan dan menjalin pertemanan dengan siswa agar lebih mudah dalam proses pengamatan. Hal ini dilakukan, karena keterampilan sosial berhubungan dengan kepiawaian seseorang dalam menjalin relasi dengan lingkungannya.

Keluarga harmonis memang sulit untuk diukur, karenanya peneliti menggunakan tolak ukur yang terdiri dari lima hal guna mengamati dan mengetahui apakah keluarga tersebut harmonis atau tidak. Kelima tolak ukur tersebut adalah terciptanya kehidupan beragama dalam keluarga, komunikasi antar anggota, waktu berkumpul bersama, saling menghargai antar anggota, dan minimnya konflik yang terjadi dalam keluarga. Kemudian peneliti memberikan ciri dari setiap tolak ukur guna memudahkan proses pengamatan ataupun wawancara. Apabila dalam keluarga telah memenuhi atau tidak memenuhi lima tolak ukur beserta aspek-aspek di dalamnya, maka keluarga tersebut dapat dikategorikan sebagai keluarga yang harmonis.

Tabel 1. Aspek-aspek Keharmonisan Keluarga

\begin{tabular}{|l|l|l|}
\hline No & Aspek yang diteliti & Ciri-ciri \\
\hline
\end{tabular}




\begin{tabular}{|l|l|ll|}
\hline 1. & Kehidupan beragama dalam keluarga & $\begin{array}{l}\text { Mengarahkan anak untuk beribadah dan shalat } \\
\text { lima waktu. } \\
\text { Menanamkan nilai-nilai moral dan etika } \\
\text { kehidupan. }\end{array}$ \\
\hline 2. & Waktu bersama keluarga & $\begin{array}{l}\text { Meluangkan waktu untuk berkumpul dan makan } \\
\text { bersama. }\end{array}$ \\
\hline 3. & Komunikasi antar anggota keluarga & $\begin{array}{l}\text { Mendengarkan masalah atau keluhan-keluhan } \\
\text { anak. }\end{array}$ \\
& $\begin{array}{l}\text { Menemani dan mengawasi anak saat bermain } \\
\text { dan belajar. }\end{array}$ \\
\hline 4. & Saling menghargai antar anggota keluarga & $\begin{array}{l}\text { Mengajak anak untuk berdiskusi dengan } \\
\text { keluarga. } \\
\text { Saling terbuka antar anggota keluarga. }\end{array}$ \\
\hline 5. & $\begin{array}{l}\text { Kenerima masukan dari masing-masing anggota } \\
\text { keluarga. }\end{array}$ \\
& didalam keluarga & $\begin{array}{l}\text { Memberikan apresiasi pada setiap prestasi yang } \\
\text { diperoleh anak. }\end{array}$ \\
\hline $\begin{array}{l}\text { Memberikan rasa aman bagi anggota keluarga. } \\
\text { Menanamkan rasa cinta dan kasih sayang } \\
\text { sesama anggota keluarga }\end{array}$ \\
\hline
\end{tabular}

Data dari hasil observasi dan wawancara dengan pedoman tersebut kemudian diolah peneliti sehingga peneliti memperoleh hasil kalau dalam indikator kehidupan beragama dalam keluarga, sepuluh responden beragama Islam sejak mereka lahir. Agama adalah sebuah sistem yang mengatur keimanan atau kepercayaan dan peribadahan terhadap Tuhan, serta kaidah yang berkaitan dengan lingkungan dan pergaulan manusia. Menciptakan kehidupan beragama dalam suatu keluarga, merupakan hal yang sangat amat penting guna terciptanya keluarga yang sakinah, mawaddah, warahmah. Selain itu agama juga penting bagi kehidupan manusia, karena agama termasuk pokok atau dasar moral, petunjuk sebuah kebenaran, dan bimbingan ruh terhadap manusia baik suka maupun duka.

Dalam agama yang mengandung nilai-nilai moral dan etika kehidupan, tidak heran kalau hal ini menjadi salah satu tolak ukur keluarga harmonis. Hasil penelitian menunjukkan dalam sepuluh keluarga terdapat enam keluarga yang menerapkan shalat berjama'ah bersama anggota keluarganya di waktu shubuh, maghrib, dan isya". Enam keluarga tersebut adalah keluarga dari Herlin Angga (Bapak Bambang-lbu Linda), Aldias (Bapak Edy-Ibu Murni), Habib Abdillah (Bapak Saifan Karjiyo-lbu Ani Sartini), Zahra (Bapak Bandiyono-lbu Yuningsih), Andre (Bapak Sarwadi-lbu Ermawati) dan Safira (Bapak Purwanto-lbu Elok). Menurut mereka, shalat berjama'ah dapat membuat suasana kekeluargaan menjadi lebih hangat dan dapat sama-sama mendekatkan diri pada Allah, selain itu berjama'ah dapat mendidik anak agar terbiasa shalat tepat waktu. Selain itu mengaji setelah shalat maghrib sudah menjadi tradisi bagi keluarga mereka, meskipun hanya dilakukan selama 5-10 menit. Menurut Ibu Ani Sartini, "mengaji adalah hal yang wajib dilakukan oleh anak-anak agar hati terasa lebih tentram, lebih damai dan hidup lebih terarah". Oleh karena itu orang tua selaku orang yang paling dekat dengan anak, harus selalu memberikan contoh akhlak yang baik, dan menanamkan nilai-nilai moral seperti memperhatikan cara berpakaian anak, dengan siapa mereka bermain, dan lain sebagainya.

Selanjutnya hasil untuk indikator waktu bersama keluarga, memberitahu peneliti bahwa sepuluh keluarga siswa menyempatkan waktu untuk berkumpul bersama sanak keluaarganya. Sebagian dari sepuluh keluarga 
siswa merupakan orang tua yang keduanya mempunyai karir, sejak pagi hari mereka sudah berangkat bekerja dan baru tiba di rumah sore atau malam menjelang isya. Meskipun demikian, mereka tidak lengah untuk memberikan hak pada keluarganya dengan menyempatkan waktu untuk berkumpul bersama keluarganya. Seperti yang dilakukan oleh Bapak Purwanto, beliau selalu mengusahakan pulang kerja lebih cepat agar dapat makan malam bersama istri dan anak-anaknya dirumah. Beliau tidak pernah ingin makan malam di luar rumah, sehingga lbu Elok (istri Bapak purwanto) dan anak-anaknya bersedia menunggunya pulang. Dengan begini perkembangan keterampilan sosial anak seperti menghargai dapat dikembangkan.

Ketersediaan waktu untuk berkumpul bersama keluarga sekilas terlihat mudah untuk dilakukan, namun tidak semua keluarga bisa melakukan hal ini. Oleh karena itu, mereka yang saling menyempatkan waktu untuk berkumpul bersama keluarga akan lebih bahagia dibanding mereka yang tidak menyempatkan sedikit waktunya untuk berkumpul bersama. Ibu Ermawati mengatakan, "dengan berkumpul bersama keluarga dapat membuat hubungan antara anggota keluarga semakin dekat dan akrab. Berkumpul bersama keluarga tidak harus bepergian ke tempat jauh atau makan di tempat mewah, tetapi cukup dengan duduk bersama dalam satu ruangan dan saling berdiskusi atau bersenda gurau satu sama lain. Sehingga, hal ini cukup mudah dilakukan dan banyak keuntungan yang di dapat seperti, anak menjadi merasa lebih nyaman ketika berada di rumah".

Secara keseluruhan, dari sepuluh keluarga siswa mereka selalu menyempatkan waktu bersama keluarga apa dan bagaiamanapun keadaannya. Mereka memiliki cara yang bermacam macam untuk berkumpul dengan keluarga. Mayoritas mereka memilih untuk duduk bersama dalam satu ruangan dan menonton tv yang diselingi dengan canda tawa. Meskipun kesepuluh keluarga merealisasikan kebersamaan antar anggota keluarganya dengan cara yang berbeda-beda, akan tetapi tujuan mereka secara garis besar sama, yaitu membuat hubungan dalam keluarga terasa dekat dan tidak membosankan atau monoton. Sehingga, seluruh anggota keluarga bisa merasakan kenyamanan dan kasih sayang yang melebihi apapun.

Kemudian indikator selanjutnya adalah komunikasi antar anggota, dalam lingkungan keluarga komunikasi sangat besar kedudukannya untuk mempertahankan kelangsungan hidup. Tanpa dibarengi dengan komunikasi yang terbuka antar anggota dalam suatu keluarga, maka keharmonisan tidak akan terjadi. Hasil data penelitian menunjukkan komunikasi sepuluh keluarga berjalan dengan sangat baik yakni saling terbuka satu sama lain, sehingga dalam keluarga jauh dari istilah miss communication. Dengan ini juga perkembangan keterampilan sosial anak seperti berkomunikasi dan berinteraksi dapat berkembang.

Menurut Ibu Linda, "komunikasi dalam keluarga beraneka ragam yaitu komunikasi verbal, non verbal, individual, dan kelompok. Akan tetapi, setiap keluarga dipastikan lebih sering menggunakan komunikasi verbal. Karena setiap hari orang tua selalu ingin berbincang-bincang kepada anaknya". Dengan terjalinnya komunikasi, anak akan lebih terbuka dengan keluarganya. Menurut lbu Yuningsih, "tidak hanya anak yang menjadi terbuka pada orang tuanya, tetapi orang tua pun bisa terbuka pada anak-anaknya sekalipun terkait ekonomi keluarga. Semisal keluarga sedang dalam kerendahan ekonomi, maka anak akan memahami hal itu".

Dan kemudian pada indikator saling menghargai, hasil data penelitian menunjukkan sepuluh keluarga dapat saling menerima masukan berupa kritik atau saran pada saat diskusi keluarga. Mereka juga menghargai setiap apa yang dilakukan masing masing anggota, seperti misalnya saat lbu di rumah sudah menyediakan makanan untuk keluarga, maka mereka menghargai hidangan tersebut dengan memakannya. Sepuluh keluarga ini pun menghargai pendapat dan keinginan anggota keluarganya. Ibu Ani Sartini menegaskan bahwa "anak juga butuh di dengar, karena dengan ini anak tidak merasa hidupnya tertekan dengan tuntutan dan 
kemauan orang tua".

Dalam sepuluh keluarga ini pun menerapkan untuk menghargai seseorang. Bapak Edy dan lbu Murni menanamkan pada anak-anaknya untuk bersikap sopan pada anggota keluarga yang ada di rumahnya, anakanak mereka tidak di perbolehkan untuk menyuruh-nyuruh anggota keluarganya dengan sesuka hatinya. Keluarga akan menjadi harmonis apabila anggota keluarga dapat meminimalisir konflik. Tidak dapat dipungkiri bahwa konflik dalam suatu rumah tangga pasti terjadi, dan yang paling penting dari itu adalah bagaimana cara menyelesaikan konflik dan menghindari konflik. Tujuh dari sepuluh keluarga responden mengatasi konflik dengan guyonan, sehingga konflik mudah sekali redam dan konflik besar hampir tidak pernah terjadi dalam keluarga. Sebenarnya konflik dapat dihindari dengan saling percaya, saling memaafkan, dan saling mengerti satu sama lain. Seperti yang dikatakan oleh lbu Nur dan Ibu Narti, rumah tangga tidak akan menjadi suram dan abu-abu bila antara suami dan istri saling percaya dan bisa memahami karakter masing-masing pasangan. Berdasarkan hasil keterangan data keharmonisan keluarga tersebut, pastinya memiliki dampak pada sikap dan kepribadian anak. Dalam keluarga yang demikian, anak akan mengalami perkembangan-perkembangan positif baik dalam segi mental maupun sosial.

Peneliti menyimpulkan, bahwa komunikasi yang baik antar anggota keluarga mampu menjadi dasar kemampuan siswa untuk berkomunikasi dengan lingkungan sosialnya. Hawari juga menjelaskan bahwa komunikasi yang efektif dengan anggota keluarga membuat anak selalu terikat secara psikologis. Dengan ini, anak akan menjadi seorang yang terbuka dengan keluarga maupun orang lain (Farida Yunistiati, dkk, 2014: 77).

\section{PENUTUP}

Berdasarkan hasil penelitian bahwasanya kontribusi keharmonisan keluarga dalam perkembangan keterampilan sosial anak di SD Negeri Bangunharjo yaitu Menciptakan kehidupan beragama dalam keluarga, Mempunyai waktu bersama keluarga, Mempunyai komunikasi yang baik antar anggota keluarga, Saling menghargai antar sesama anggota keluarga. Kualitas dan kuantitas konflik yang minim. Adanya hubungan atau ikatan yang erat antar anggota keluarga. Dimana dari keluarga yang harmanonis anak dapat mengembangkan keterampilan sosial mereka seperti kemampuan komunikasi, sikap saling menghargai dan dapat diajarkan berhubungan dan menyelesaikan konflik dengan baik. Karena dengan sering berkumpul bersama keluarga, emosi mereka secara tidak langsung sudah terlatih, yang pada akhirnya siswa menjadi mudah bersosialisasi dan berinteraksi.

\section{DAFTAR PUSTAKA}

Agus Efendi. (2005). Revolusi Kecerdasan Abad 21 Kritik MI, EI, SQ, AQ \& Successful Intelligence Atas IQ. Alfabeta.

Awi, M. V., Mewengkang, N., \& Golung, A. (2016). Peranan Komunikasi Antar Pribadi Dalam Menciptakan Harmonisasi Keluarga di Desa Kimaamkabupaten Merauke. Acta Diurna Komunikasi, 5(2).

Departemen Pendidikan Nasional. (2005). Kamus Besar Bahasa Indonesia, Cet Ke -3. Balai Pustaka.

Eriyanti, I. O., Susilo, H., \& Riyanto, Y. (2019). Analisis Pola Asuh Grandparenting Dalam Pembentukan Karakter Anak di TK Dharma Wanita Di Desa Drokilo Kecamatan Kedungadem Kabupaten Bojonegoro. Jpus: Jurnal Pendidikan Untuk Semua, 3(1), 9-16.

Farida Yunistiati, M. As"Ad Djalali, Muhammad Farid. (2014). Keharmonisan Keluarga Konsep Diri Dan Interaksi Sosial Remaja. Persona, Jurnal Psikologi Indonesia, 03(01). 
Helmawati. (2014). Pendidikan Keluarga. Pt Remaja Rosdakarya.

Isminayah, A., \& Supandi. (2016). Relasi Tingkat Keharmonisan Keluarga Dengan Konsep Diri Remaja. Al-Balagh : Jurnal Dakwah Dan Komunikasi, 1(2), 233-248.

John Gottman Dan Joan Declaire. (2008). Mengembangkan Kecerdasan Emosional Anak. PT Gramedia Pustaka Utama.

Muchtar, A. I., Darwis, M., \& Muhammad, R. (T.T.). Pengaruh Keharmonisan Keluarga Dan Lingkungan Sekolah Terhadap Prestasi Belajar Bidang Studi Sosiologi. 9.

Musdalipah, M., Holilulloh, H., \& Nurmalisa, Y. (2015). Pengaruh Pemahaman Nilai-Nilai Pancasila Terhadap Kemampuan Sosial Siswa (No. 6). 3(6).

Nidyansari, D. A. (2018). Ketidakharmonisan Komunikasi Dalam Keluarga Pada Pembentukan Pribadi Anak (Pendekatan Humanistik). Jurnal Riset Komunikasi, 1(2), 264-275.

Nur Ahid. (2010). Pendidikan Keluarga Dalam Perspektif Islam. Pustaka Belajar.

Saputri, E. M. (2014). Hubungan Interaksi Sosial Dan Keharmonisan Keluarga Dengan Perilaku Agresif Pada Siswa Kelas X Di Smk Negeri I Baureno-Bojonegoro. Jurnal Bk Unesa, 4(2).

Sari, D. N. E. P., \& Kristiawan, I. (2017). Pola Keterampilan Sosial Dalam Manajemen Konflik Berbasis Pluralitas Mahasiswa di Kawasan Pemukiman Warga (Studi Kasus Pada Mahasiswa Di Kawasan Perumahan Asabri RW IX Kelurahan Sawojajar Kecamatan Sawojajar Kota Malang). Prosiding Snapp: Sosial, Ekonomi Dan Humaniora, 5(1), 309-314.

Setiawati, F. A. (2009). Pendekatan Humanistik Dalam Bimbingan Konseling di Sekolah Untuk Mengembangkan

Helfer, M. E., Kempe, R. S., \& Krugman, R. D. (2000). The battered child (5 $5^{\text {th }}$ ed.). Chicago, IL: University of Chicago Press.

Wahyuni, S. Y. (2009). Pengembangan uji kompetensi mandiri berbasis komputer untuk meningkatkan efikasi diri siswa (Doctoral dissertatation). Retrieved from name of database

\section{Dissertation/Thesis, Unpublished}

Kuntoro, T. H. (2007). Pengembangan kurikulum pelatihan magang di SMK : Suatu studi berdasarkan dunia usaha (Unpublished Doctoral dissertation). Program Pasca Sarjana UNNES, Semarang.

\section{Government Document}

National Institute of Mental Health. (2008). Clinical training in serious mental illness (DHHS Pubication No. ADM 90-1679). Washington, DC : U. S. Government Printing Office.

\section{Conference Proceedings}

Suci, P., Tjipto, P., \& Budi, J. (Eds.). (2013). Implementasi penggunaan simulasi phET dan KIT sederhana untuk mengajarkan keterampilan psikomotor siswa. , Prosiding Seminar Nasional IPA IV . Semarang: Program Studi Pendidikan IPA S1 FMIPA UNNES. 